\title{
PCR-RFLP Analysis of Single Nucleotide Polymorphism (SNP) C-2402T at the Promoter Region of Prolactin Gene and its Association with Positively Correlated Production Traits in White Leghorn Chicken
}

Azhaguraja Manoharan¹, S. Sankaralingam, P. Anitha, Binoj Chacko, T.V. Aravindakshan

10.18805/IJAR.B-4391

\begin{abstract}
Background: The avian prolactin gene is highly conserved, located on chromosome number 2 and most sequence polymorphisms occurs in the 5' flanking region, 3' flanking region, and the coding region of signal peptide. The present study was aimed at the identification of SNP C-2402T of prolactin gene and its association with production traits in White Leghorn chicken.

Methods: A total of 200 birds of White Leghorn were selected from All India Co-ordinated Research Project on Poultry improvement (AICRP) farm, Mannuthy. Genomic DNA was isolated from venous blood. Polymerase chain reaction (PCR) followed by restriction fragment length polymorphism (RFLP) analysis was done to identify the SNP C-2402T of prolactin gene.

Result: All the birds were observed with the same genotype CC and the frequency of the $C$ allele was one.

Key words: Genotype, PCR, Prolactin, RFLP, SNP, White Leghorn.
\end{abstract}

\section{INTRODUCTION}

In Indian agriculture, the poultry industry is one of the fastestgrowing sectors among all livestock sectors. At present, the total poultry population in our country is about 851.81 million numbers as per the $20^{\text {th }}$ livestock census (Government of India, 2020) and the egg production of around 103.318 billion numbers (BAHS, 2019). Persistent efforts and collaborative research on poultry breeding have been carried out for the evolution of high producing layer stock which is suitable for various environment and management practices (Tomar et al., 2015). White Leghorn is a non-broody bird and produces more than 300 eggs per year. On one hand, the non-broody behaviour of White Leghorn is due to the presence of a major autosomal recessive gene on the $Z$ chromosome (Romanov, 2001). On another hand, a 24bp insertion polymorphism at the promoter region of the prolactin gene suppresses the expression of the prolactin gene, and broodiness is prevented (Jiang et al., 2005). Also, White Leghorn is used as a major line in the cross-breeding programmes to develop different layer strains for high egg production in the commercial poultry industry. Poultry breeding is done mainly to increase the level of egg-laying capacity, egg quality and meat quality (Kulibaba et al. 2020). Over the past few years, newer DNA technologies, markerassisted selection and genomic selection have been efficiently employed in poultry selection and breeding (Salisu et al., 2018). The foremost objective of commercial poultry breeding is to achieve genetic improvement in age at sexual maturity, egg weight, egg number and body weight. Restriction fragment length polymorphism (RFLP) enables to detection of the large insertion and deletion within the
Department of Poultry Science, College of Veterinary and Animal Sciences, Mannuthy, Thrissur-680 651, Kerala, India.

${ }^{1}$ ICAR-Indian Veterinary Research Institute, Izzatnagar, Bareilly243 122, Uttar Pradesh, India.

Corresponding Author: Azhaguraja Manoharan, ICAR-Indian Veterinary Research Institute, Izzatnagar, Bareilly-243 122, Uttar Pradesh, India. Email: azhagurajamano@gmail.com

How to cite this article: Manoharan, A., Sankaralingam, S., Anitha, P., Chacko, B. and Aravindakshan, T.V. (2021). PCR-RFLP Analysis of Single Nucleotide Polymorphism (SNP) C-2402T at the Promoter Region of Prolactin Gene and its Association with Positively Correlated Production Traits in White Leghorn Chicken. Indian Journal of Animal Research. DOI: 10.18805/IJAR.B-4391.

Submitted: $30-12-2020$

Accepted: 27-08-2021

Online: 24-09-2021

genome sequence and to identify of the single base changes called single nucleotide polymorphism (SNP) (Fulton, 2012). The chicken prolactin gene plays a significant role in egg production (Wang et al., 2011). Since the avian prolactin gene was cloned and sequenced, most of the research has focused on detecting new polymorphic sites in this gene. The results of several studies had shown a significant association of SNPs of prolactin gene with economically important traits in different species of poultry (Wilkanowska et al., 2014). Specifically, a significant association was found between the SNP of C-2402T genotypes with egg number and laying rate in Fars native chicken (Bagheri Sarvestani et al., 2013). Thus, this study aimed to study was to identify the SNP C-2402T at the promoter region of the prolactin gene using the PCR- RFLP technique and find out the 
association of this SNP with production traits in White Leghorn chicken.

\section{MATERIALS AND METHODS Experimental birds}

A total of 200 birds of White Leghorn were randomly selected during September 2016 to October 2017 from the All India Research Co-ordinated Project (AICRP) on poultry improvement, Mannuthy, Thrissur, Kerala, India.

\section{Workplace}

The present study was carried out at Avian Biotechnology Laboratory, in the Department of Poultry Science, Kerala Veterinary and Animal Sciences University, Mannuthy, Thrissur, Kerala.

\section{Collection of blood samples}

Approx. $0.5-1 \mathrm{ml}$ of blood was collected from the wing vein under aseptic conditions. The samples were brought to the laboratory at $4^{\circ} \mathrm{C}$ in an ice pack.

\section{Isolation of genomic DNA}

Isolation of Genomic DNA was done from the whole blood using ODP304 Origin Genomic DNA isolation kit according to the standard procedure given by manufacturers. The yield and quality of the DNA obtained were checked by Nanodrop spectrophotometer and by $0.8 \%$ agarose gel electrophoresis, respectively. The DNA samples showing the OD260/OD280 ratio between 1.7 and 1.9 were used for further investigation.

\section{PCR assay}

The polymerase chain reaction was carried out using a specific set of forward (F-5' AGAGGCAGCCCAGGCAT TTTAC3') and reverse primer (R-5'CCTGGGTCTGGTTTGG AAATTG3') to amplify the 439bp fragment of prolactin gene containing SNP C-2402T at the promoter region (Cui et al., 2006; Bagheri Sarvestani et al., 2013). Each diluted primer $(10 \mathrm{pM} / \mu \mathrm{l})$ was added to the template DNA $(100 \mathrm{ng} / \mu \mathrm{l})$ and 2X PCR Smart Mix (origin) in a PCR tube and made up to the final volume of $20 \mu \mathrm{l}$ using ultra-filtered Millipore water. PCR was done in Bio-Rad thermal cycler and standardization was done with the following program: initial denaturation of 5 min at $94^{\circ} \mathrm{C} ; 35$ cycles of $94^{\circ} \mathrm{C}$ for $30 \mathrm{~s}$, annealing at $67.7^{\circ} \mathrm{C}$ for $30 \mathrm{~s}$, and $72^{\circ} \mathrm{C}$ for $30 \mathrm{~s}$ with a final elongation of $5 \mathrm{~min}$ at $72^{\circ} \mathrm{C}$. PCR amplicons were checked on $2 \%$ agarose gel.

\section{Agarose gel electrophoresis}

The genomic DNA and PCR products were checked in agarose gels of 0.8 per cent and $2 \%$, respectively prepared using 1X TBE buffer. The PCR products were loaded along with a molecular weight marker (50bp ladder) for relative sizing. Electrophoresis was carried out at $5 \mathrm{~V} / \mathrm{cm}$ and the gel was photographed in a Gel Doc System (Bio-Rad, USA).

Restriction fragment length polymorphism (RFLP) analysis

For restriction digestion five microlitres of the amplified PCR product (439bp) of promoter $\mathrm{C}-2402 \mathrm{~T}$ was added with 5 units of Alul enzyme and incubated at $37^{\circ} \mathrm{C}$ for $1 \mathrm{hr}$. The composition of the reaction mixture was made with the final volume of $12 \mu \mathrm{l}$ (PCR product-5 $\mu \mathrm{l}$, 10X buffer $-1.2 \mu \mathrm{l}$, Alul $(10 \mathrm{U} / \mu \mathrm{l})-0.5 \mu \mathrm{l}$ and Distilled water $-5.3 \mu \mathrm{l})$. After restriction digestion, the digested PCR products were separated by electrophoresis in $3 \%$ agarose gel in $1 \mathrm{X}$ buffer with $50 \mathrm{bp}$ DNA size marker. The restriction pattern was visualized under a UV trans-illuminator and documented in a gel documentation system.

The amplicons of the promoter region of prolactin gene 439bp and the digested PCR products were sequenced using respective forward and reverse primers in an automated sequencer using Sanger's dideoxy chain termination method at Agri Genome Labs Pvt. Ltd., Cochin, Kerala. Based on the results of RFLP analysis, all the birds were designated with the same genotype and allele frequency was calculated, accordingly. Bodyweight at $16^{\text {th }}$, $40^{\text {th }}$ and $64^{\text {th }}$ weeks of age, and egg weight at $28^{\text {th }}, 40^{\text {th }}$ and $64^{\text {th }}$ weeks of age, respectively were recorded.

\section{Statistical analysis}

The association of SNP site C-2402T of prolactin with body weight and egg weight were analyzed by one-way ANOVA by using the software SPSS (Version 21.0).

\section{RESULTS AND DISCUSSION}

The quality of extracted DNA was checked on $0.8 \%$ agarose gel (Fig 1) PCR amplification of 439bp amplicon of prolactin gene is represented on $2 \%$ agarose gel (Fig 2). On restriction analysis, 439bp PCR products of prolactin with Alul restriction enzyme revealed the presence of only one genotype CC with different sizes of restriction fragments (160, 144, 81 and 54bp) on $3 \%$ agarose gel (Fig 3). The same RFLP pattern was observed in all 200 digested products of PCR samples. Simultaneously, this Alul restriction enzyme has been widely used in most of the studies to reveal the restriction sites for the SNP position C$2402 \mathrm{~T}$ in the chicken prolactin gene (Cui et al., 2006; Kulibaba et al., 2012; Bagheri Sarvestani et al., 2013; Kulibaba, 2015). Also, we applied the NEBcutter V2.0 tool to identify the restriction sites within our DNA sequence and found Alul restriction enzyme was suitable for the SNP site $\mathrm{C}-2402 \mathrm{~T}$ of the prolactin gene. Therefore, we have planned to proceed with our research work further but we have not gone through any pilot study for the present work using the Alul restriction enzyme. According to the restriction digestion results, it had been confirmed that all the 200 birds of White Leghorn chicken were monomorphic with the same genotype CC for the SNP site C-2402T of prolactin gene. Thus, no polymorphism were found in this White Leghorn chicken population which had undergone 29 generations of continuous selection. In contrary to our findings, the Alul restriction enzyme produced different sizes of fragments with three genotypes viz. CC (four fragments- 160, 144, 81 and 54bp), CT (five fragments- 304, 160, 144, 81 and 54bp) and TT (three fragments - 304, 81 and $54 \mathrm{bp}$ ), respectively for 
PCR-RFLP Analysis of Single Nucleotide Polymorphism (SNP) C-2402T at the Promoter Region of Prolactin Gene and its...

the SNP site C-2402T of prolactin gene in Fars native chicken of Iran (Bagheri Sarvestani et al., 2013). Similarly, all three genotypes CC, CT and TT were observed in five different chicken populations (Yangshan, Taihe Silkies 1, White Rock, Nongdahe and Taihe Silkies 2) with six SNPs (Cui et al., 2006). Also, Chau, (2016) reported similar findings in the Noi native chicken of Vietnam. In comparison, Kulibaba et al. (2015) conducted research on polymorphism of prolactin gene in connection with egg production in
Poltava clay chicken of Ukraine and found SNP at the position of C-2402T with all three possible genotypes in this population. Allele $C$ had three restriction sites for Alul (two monomorphic and one polymorphic) and allele $\mathrm{T}$ had two restriction sites. Similar polymorphism (C-2402T) was reported by Kulibaba et al. (2012) in chicken lines of Ukrainian selection.

Our findings revealed that all 200 birds of White Leghorn chicken carry CC genotype. As a result, all White Leghorn

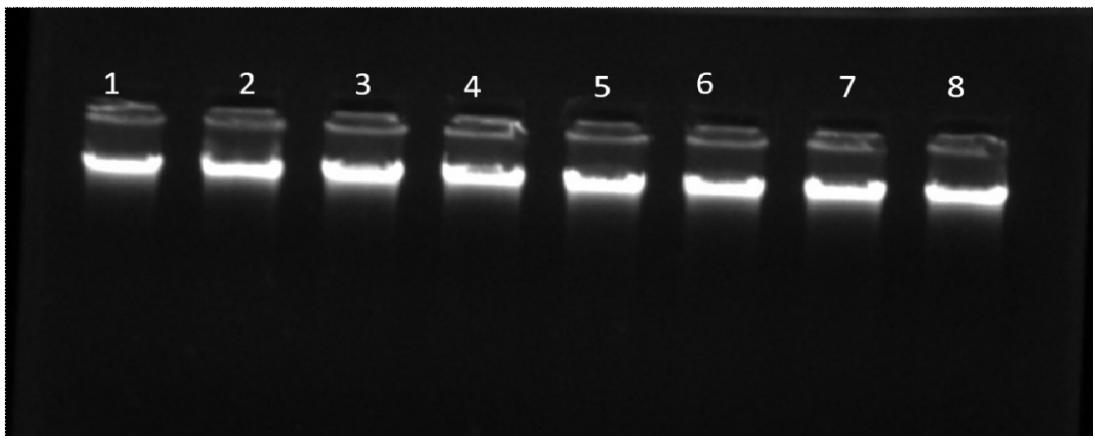

Fig 1: Testing the quality of extracted Genomic DNA on $0.8 \%$ agarose gel Lane 1-8: Genomic DNA isolated from venous blood.

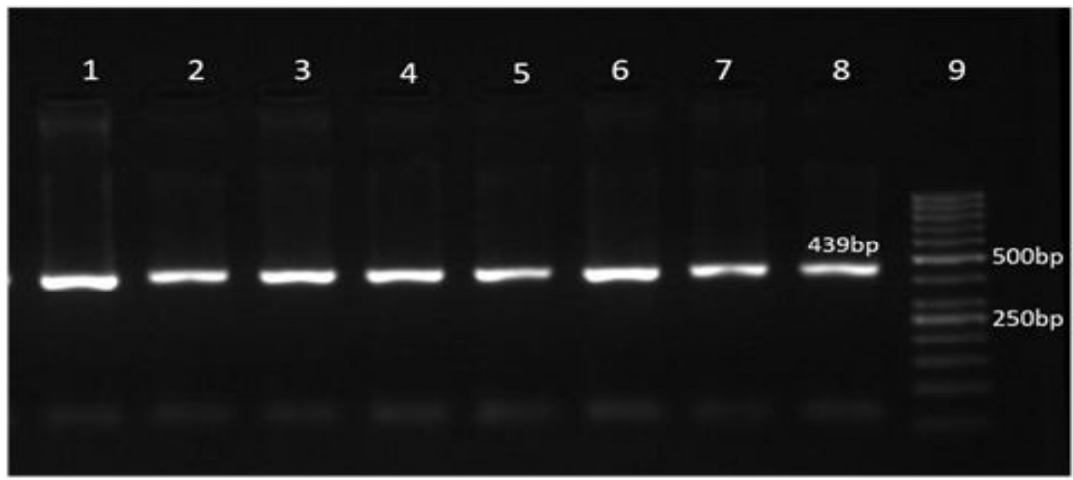

Fig 2: PCR amplification of $439 \mathrm{bp}$ fragment of prolactin gene on $2 \%$ agarose gel Lane 1- $8:$ 439bp PCR product.

Lane 9: $50 \mathrm{bp}$ ladder.

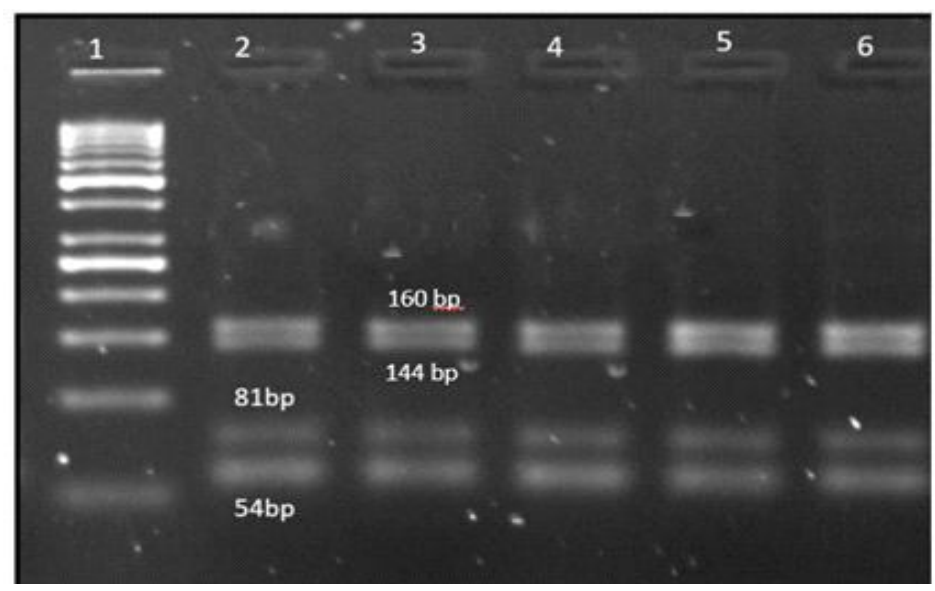

Fig 3: RFLP analysis of $439 \mathrm{bp}$ fragment of prolactin gene digested with Alul on $3 \%$ agarose gel. Lane 1 : 50bp Ladder.

Lane 2-6:160,144, 81 and 54bp restriction fragments of CC genotype. 
chicken selected from the AICRP farm are monomorphic for the allele $C$ and the allele frequency of $C$ was 1.0 in this population. Similar findings were reported by Cui et al. (2006) in the White Leghorn chicken population for the SNP site C-2402T. In contrary to these findings, Bagheri Sarvestani et al. (2013) reported the allele frequency as $0.66(\mathrm{C})$ and $0.34(\mathrm{~T})$ in Fars native chicken of Iran. In comparison, Chau. (2016) found the allele frequency as $C(0.17)$ and $T(0.83)$ in the Noi native chicken of Vietnam. Furthermore, Kulibaba et al. (2015) reported the allele frequency as $C(0.372)$ and $\mathrm{T}(0.628)$ in the Poltava clay chicken population of Ukraine. In addition, Kulibaba et al. (2012) found the allelic frequency as $C(0.745)$ and $T(0.255)$ for the chicken line $A$ in Ukrainian selection. According to these research findings, it has been observed that frequency of the $C$ allele varies in different breeds of the chicken population. Allele frequency is a measure of the relative frequency of an allele on a genetic locus in a population and usually, it is expressed as a proportion or a percentage. Hence, the variation in allele frequency is possibly due to gene flow, genetic drift, natural selection, and mutation. These are referred to as the four fundamental forces of evolution. Besides, the mutation can create new genetic variation and the other three forces simply rearrange this variation within and among populations.

\section{Association of SNP C-2402T at the promoter of prolactin gene with body weight and egg weight in White Leghorn chicken}

Bodyweight at $16^{\text {th }}, 40^{\text {th }}$ and $64^{\text {th }}$ weeks of age and egg weight at $28^{\text {th }}, 40^{\text {th }}$ and $64^{\text {th }}$ weeks of age, respectively were recorded for all 200 birds of White Leghorn which were randomly selected from AICRP on poultry improvement farm, Mannuthy, Thrissur. By the acquired statistical results, the mean body weight at $16^{\text {th }}, 40^{\text {th }}$ and $64^{\text {th }}$ weeks of age were $1036.75 \pm 2.62,1561.00 \pm 6.07$ and $1544.00 \pm 6.31 \mathrm{~g}$ and mean egg weight at $28^{\text {th }}, 40^{\text {th }}$ and $64^{\text {th }}$ weeks of age were $48.00 \pm 0.01,52.16 \pm 0.10$ and $54.16 \pm 0.37 \mathrm{~g}$, accordingly for the genotype CC of SNP site C-2402T. Since only CC genotype was found in this White Leghorn chicken population, association study with positively correlated traits was not possible.

\section{CONCLUSION}

Our research findings revealed the presence of only one genotype CC for the SNP site C-2402T of prolactin gene in all the 200 birds of White Leghorn chicken using PCR- RFLP analysis. It indicates that the prolactin gene is monomorphic for this chicken population and the frequency of the $\mathrm{C}$ allele was one. Hence, further research could be done in other breeds of the chicken population to confirm the association of SNP C-2402T of prolactin gene with production traits.

\section{ACKNOWLEDGEMENT}

The current research was funded by the Kerala state plan project. I would like to thank the Professors, staff of the Department of Poultry Science and the Department of Animal
Breeding and Genetics. Also to the Dean, College of Veterinary and Animal Sciences, Mannuthy, Thrissur, Kerala for providing the necessary infrastructure required for the investigation of the present research.

\section{REFERENCES}

Bagheri Sarvestani, A.S., Niazi, A., Zamiri, M.J. and Dadpasand Taromsari, M. (2013). Polymorphisms of prolactin gene in a native chicken population and its association with egg production. Iranian Journal of Veterinary Research. 14: 113-119.

Basic Animal Husbandry Statistics (2019). Government of India. Ministry of Fisheries, Animal Husbandry and Dairying. Department of Animal Husbandry and Dairying.

Chau, T.V. (2016). Single nucleotide polymorphisms in candidate genes associated with egg production traits in native Noi chicken of Vietnam. International Journal of Plant, Animal and Environmental Sciences. 6: 162-169.

Cui, J.X., Du, H.L., Liang, Y., Deng, X. M., Li, N. and Zhang, X.Q. (2006). Association of polymorphisms in the promoter region of chicken prolactin with egg production. Poultry Science. 85: 26-31.

Fulton, J.E. (2012). Genomic selection for poultry breeding. Animal Frontiers. 2: 30-36.

Government of India. (2020). Annual Report 2019-20. Department of Animal Husbandry, Dairying and Fisheries, Ministry of Agriculture.

Jiang, R. S., Xu, G. Y., Zhang, X. Q. and Yang, N. (2005). Association of polymorphisms for prolactin and prolactin receptor genes with broody traits in chickens. Poultry Science. 84: 839-845.

Kulibaba, R.A. (2015). Polymorphism of growth hormone, growth hormone receptor, prolactin and prolactin receptor genes in connection with egg production in Poltava clay chicken. Agricultural Biology. 50: 198-207.

Kulibaba, R.A. and Podstreshnyi, A.P. (2012). Prolactin and growth hormone gene polymorphisms in chicken lines of Ukrainian selection. Cytology and Genetics. 46: 390-395.

Kulibaba, R.O., Sakhatskyi, M.I., Liashenko, Y.V., Yurko, P.S. and Osadcha, Y.V. (2020). Functional genes polymorphism associations with egg quality traits in the populations of dual-purpose. Agricultural Science and Practice. 7: 14-23.

Romanov, M.N. (2001). Genetics of broodiness in poultry-a review. Asian-Australasian Journal of Animal Sciences. 14: 1647-1654.

Salisu, I.B., Olawale, A.S., Jabbar, B., Koloko, B.L., Abdurrahaman, S.L., Amin, A.B. and Ali, Q. (2018). Molecular markers and their potentials in animal breeding and genetics. Nigerian Journal of Animal Science. 20: 29-48.

Tomar, A., Poonia, J., Chaudhari, M. and Kumar, P. (2015). Evaluation of production Performance of some economic traits in White Leghorn birds. Haryana Veterinarian. 54: 19-21.

Wang C., Liang Z., Yu W., Feng Y., Peng X. and Gong Y. (2011). Polymorphism of the prolactin gene and its association with egg production traits in native Chinese ducks. South African Journal of Animal Science. 41: 64-69.

Wilkanowska, A., Mazurowski, A., Mroczkowski, S. and Kokoszyñski, D. (2014). Prolactin (PRL) and prolactin receptor (PRLR) genes and their role in poultry production traits. Folia Biologica (Kraków). 62: 1-8. 